\title{
CHANGES IN MACRONUTRIENTS AND PHYSICAL PROPERTIES DURING THE GROWTH OF Lentinula edodes AND Pleurotus ostreatus IN A COMPOST BASED ON SUGARCANE BAGASSE AGRICULTURAL WASTE
}

\author{
Laura Narváez ${ }^{1 \mathrm{a}}$, Ana Cristina Bolaños ${ }^{1 \mathrm{~b} *}$, Adriana Chaurra ${ }^{2}$, and Orlando Zuñiga Escobar ${ }^{3}$ \\ ${ }^{1 a}$ Facultad de Ciencias Naturales y Exactas, Departamento de Biología, Grupo de Investigación en \\ Biología de plantas y microorganismos (GPM), Universidad del Valle. Calle 13 No. 100-00, Cali, \\ Colombia \\ https://orcid.org/0000-0002-1808-851X \\ ${ }^{1 b}$ Facultad de Ciencias Naturales y Exactas, Departamento de Biología, Grupo de Investigación en \\ Biología de plantas y microorganismos (GPM), Universidad del Valle. Calle 13 No. 100-00, Cali, \\ Colombia \\ https://orcid.org/0000-0003-0882-2351 \\ 2 Facultad de Ciencias básicas, Departamento de Ciencias Ambientales, Grupo de Investigación en \\ Estudios Ambientales para el Desarrollo Sostenible (GEADES), Universidad Autónoma de Occidente. \\ Calle 25, Vía Cali - Puerto Tejada \#115-85 Km 2. Cali, Colombia https://orcid.org/0000-0001-6277- \\ 4245 \\ 3 Facultad de Ciencias Naturales y Exactas, Departamento de Física, Grupo de Investigación en Ciencias \\ Ambientales y de la Tierra (ILAMA), Universidad del Valle. Calle 13 No. 100-00, Cali, Colombia \\ https://orcid.org/0000-0003-4434-8597 \\ *Corresponding author E-mail: ana.bolanos@correounivalle.edu.co
}

\section{ABSTRACT}

Spent mushroom substrate of different edible mushrooms is a nutrient-rich biomass associated with mycelial metabolic activity in the growth substrate. The objective of this study was to evaluate the changes in the nutritional content and physical properties of a sugarcane bagasse substrate after the cultivation of the edible mushrooms Pleurotus ostreatus and Lentinula edodes. Strains of both species were first propagated in potato dextrose agar culture medium, then in wheat grains, and finally inoculated in sterile sugarcane bagasse. Determinations of macronutrients, $\mathrm{pH}$ and C:N ratio were carried out at 0,30 and 60 days after mushroom mycelium growth in the bagasse-based substrate. After 30 and 60 days of inoculation, nitrogen $(\mathrm{N})$, phosphorous $(\mathrm{P})$ and potassium (K) recorded increases of $0.26 \%, 0.06 \%$ and 0.14 with Pleurotus ostreatus, and increases of $0.33 \%, 0.05 \%$, and $0.11 \%$ with Lentinula edodes, respectively. Regarding micronutrients, there was an increase in Calcium (Ca) and Sulphur (S) in both substrates, but amounts varied during the time evaluated. Additionally, an important increase in hydrogen ion concentration was observed when both species were inoculated, with final values of 4.26 and 3.9 for Pleurotus ostreatus and Lentinula edodes species, respectively. In conclusion, this biomass presents a high percentage of the essential micro and macro elements required in a fertilizer.

Key words: Biofertilizer, nitrogen, biomass, spent mushroom substrate. 


\section{INTRODUCTION}

Lentinula edodes and Pleurotus ostreatus, species of the Basidiomycota phylum, are among the five species with the highest market demand for edible fungi in the world (Royse et al., 2017). Mushroom sporocarps are characterized by their edible potential as they are a rich source of protein with high contents of essential amino acid, vitamin (B1, B2, B12, C, D, E), minerals, water and fiber as well as low levels of fat (Heleno et al., 2010; Ouzouni et al., 2009). In addition, sporocarps of many mushroom species are used for their medicinal value because of their active biological compounds with antibacterial, antifungal, antiparasitic, antidiabetic, antiallergic, anticholesterolemic, antioxidant, immunomodulating, and antitumor properties (Chang and Wasser, 2012; Sari et al., 2016). The world market for edible mushrooms was US \$ 42,419 billion dollars in 2018, but is expected to grow to US $\$ 62,193$ billion dollars in 2023 (https:// www.knowledge-sourcing.com/products/ global-edible-mushrooms-market-industrytrends-opportunities-and-forecasts-to-2023). This will result in an increased production of spent mushroom substrate (SMS) or spent mushroom compost (SMC), which is a by-product after the harvest of edible mushrooms (Owaid et al., 2017). This compost is made from agricultural waste such as tea leaves, banana, cotton, corn husk, coffee husks, sugarcane bagasse, cereal straw, and wood sawdust. In the cultivation of Agaricus spp., horse manure, chicken manure, urea, ammonium sulfate, blood meal, grape pomace, molasses, brewers' grain and feather flour are added as supplements to increase soil nitrogen content (Stamets, 1983; Kamthan and Tiwari, 2017; PardoJimenez et al., 2016; Pardo-Jimenez et al., 2018).

These substrates have high content of polysaccharide, vitamin, and trace elements, such as $\mathrm{Fe}, \mathrm{Ca}, \mathrm{Zn}$ and $\mathrm{Mg}$ (Medina et al., 2009; Zhu et al., 2012). They also have extracellular enzymes produced by edible fungi to carry out efficient lignin degradation (Pandey et al., 2014; Singh and Singh, 2012) as well as cellulose and hemicellulose degradation (Kabet et al., 2017; Vos et al., 2017). In China, which is the largest producer of edible fungi (Liu et al., 2015), it is estimated that $4-5 \mathrm{~kg}$ of SMC are generated for each $\mathrm{kg}$ of fungi produced (Law et al., 2003; Medina et al., 2012; Phan and Sabaratnam, 2012). SMC is reused in mushroom cultivation (Wang et al., 2015) and animal feed (Ayala et al., 2011; Kim et al., 2011; Chang et al., 2016; Foluke et al., 2014), and the enzymes can be recovered (Phan and Sabaratnam, 2012; Rodriguez et al., 2012; Lim et al., 2013; Raymond et al., 2015). In fact, the substrate is used as a substitute for peat (Abad et al., 2001) in bioremediation (Stanley et al., 2018; Marin-Benito et al., 2016), and for bioethanol production (Hiyama et al., 2011), pest management (Ahmad et al., 2016), and packaging and construction materials (Appels et al., 2018; Xing et al., 2018; Jones et al., 2017). SMC is also used as a soil conditioner and for the recuperation of degrade soils in agriculture (Gümüs and Seker, 2017; Jankowski et al., 2018; Unal, 2015). In this sense, the addition of depleted compost to the soil can result in positive effects such as the development of a granular microstructure in the A horizon and a spongy structure in the B horizon (Nakatsuka et al., 2016), and also increased biological activity (Balesdent et al., 2000), where fungi play an important role because they modulate soil strcuture. As the hypha grow, they stabilize, agglutinate, and decompose organic matter (binding soil grains into granular aggregates), and realign particulate materials on a micrometric scale (Tisdall and Oades, 1982; Ritz and Young, 2004). According to Gümüş and Şeker, (2018), addition of spent compost to the soil improves electrical conductivity, total nitrogen, organic carbon, aggregate stability, and soil modulus of rupture, and thus represents an environmentally friendly alternative, particularly because there is an emerging demand to increase agricultural sustainability while decreasing dependence on chemical fertilizers.

In Colombia, agriculture accounts for $6.3 \%$ of the gross domestic product of the country (Cárdenas et al., 2018). Sugarcane is one of the main crops in Colombia, being particularly grown in the Valle del Cauca region, where consequently large quantities of bagasse are produced. In 2015, Valle del Cauca generated an average of 7,261,526 tons of bagasse, of which $15 \%$ was used for paper production, and the remaining $85 \%$ was used in the production of bioethanol and the generation of energy in sugar mill boilers. Even though bagasse has different uses, it has not been clearly determined yet whether it might be socially and environmentally sustainable (Becerra-Quirós et al., 2016).

Sugarcane bagasse is a suitable substrate for the growth of $L$. edodes and P. ostreatus. Edible fungi production constitutes a process in which a low-quality residue with a negative environmental impact is converted into highquality food and waste (SMS) with the potential to be used in the production of biofertilizers (Gerdelidani and Hosseini, 2018). These features could play a key role in the development of an integrated nutrient management system that contributes to the sustainability of regional agriculture, and to the implementation of circular 
economy practices in the region. It is well known that biofertilizers increase the size and volume of plant roots, enhancing the efficiency of plants to obtain water and expanding their life span. Unlike synthetic fertilizers, biofertilizers are sources of bioavailable nutrients that can be slow released (Malusà and Canfora, 2016).

The objective of this study was to evaluate the changes in the nutritional content and physical properties of sugarcane bagasse-based compost during the mycelial growth of the edible mushrooms $P$. ostreatus and L. edodes. The potential of the substrate as a biofertilizer was evaluated.

\section{MATERIALS AND METHODS}

\section{Obtaining degradable substrate}

Sugarcane bagasse was collected at the "Palestina" sugar mill, located at Kilometer 6 on the road to the town of Candelaria in Valle del Cauca state. The collected bagasse was stored in a dry, covered area. A homogeneous sample of bagasse was taken with a fiber size of between 3 and $5 \mathrm{~cm}$ to facilitate the effective invasion of $P$. ostreatus and L. edodes mycelium.

\section{Strains and spawn preparation}

Strains of $P$. ostreatus and $L$. edodes were obtained from the fungal culture collection of the Department of Biology of the Universidad del Valle (Colombia). At the laboratory of the Department of Biology, mycelium fragments of both fungi were inoculated in Petri dishes containing potato dextrose agar (PDA) for reactivation and to check viability. The mycelial growth of each species in this culture medium was used to prepare the spawn in wheat grain.

\section{Spawn production}

Wheat grain was first washed, and after $\mathrm{CaCO}_{3}$ and $\mathrm{CaSO}_{4}$ were added, it was boiled for 15 minutes, drained, placed in glass jars, sealed and sterilized for one hour at $122{ }^{\circ} \mathrm{C} 1.5 \mathrm{~atm}$. Grown mycelium pieces of $1 \mathrm{~cm}^{2}$, obtained in PDA plates, were inoculated into a glass jar containing sterile grain wheat once they reached room temperature. They were incubated at $28^{\circ} \mathrm{C}$ for three weeks.

\section{Substrate}

Sugarcane bagasse was used as growth substrate. Two tests were conducted for each fungal species. Water was added to obtain 70$80 \%$ humidity. Plastic bags containing $500 \mathrm{~g}$ of the substrate were sealed and sterilized during one hour at $122{ }^{\circ} \mathrm{C}$ and $1.5 \mathrm{~atm}$. After cooling, each sterilized substrate was inoculated with $15 \mathrm{~g}$ spawn $(3 \%)$, and then incubated at $26^{\circ} \mathrm{C}$.

\section{Chemical analysis}

Neutral detergent fiber (NDF), acid detergent fiber (ADF) and acid detergent lignin (ADL) analyses were used to determine hemicellulose, cellulose, and lignin contents of the substrates. Total nitrogen (Automated Molecular Spectrophotometry with acid digestion Standard Method D8083-16), total carbon (gravimetric method with incineration at $450{ }^{\circ} \mathrm{C}$ ), phosphorus (Automated Molecular Spectrophotometry with acid digestion), calcium, magnesium, sodium, and potassium (Inductively Coupled PlasmaOptical Emission Spectrometry, Standard Method 3120) were analyzed in sugarcane bagasse at 0,30 and 60 days of the colonization process by each inoculated species. Bagasse $\mathrm{pH}$ was measured using a $\mathrm{pH}$ meter (Metrohm 914), and a water ratio of 10: 100 was used. The initial $\mathrm{C}: \mathrm{N}$ ratio was obtained by dividing the nitrogen percentage by the carbon percentage obtained by the gravimetric method.

\section{Statistical analysis}

The experiments were arranged in a completely randomized design to test three replicates of $P$. ostreatus and $L$. edodes at 0,30 days and 60 days. The results obtained in the chemical characterization were processed using SAS 9.4 statistical software. Descriptive statistics such as means, variances, and standard deviations were calculated. Significant differences were compared by using Leneve's Test at a significance level of $5 \%$.

\section{RESULTS AND DISCUSSION}

\section{$\mathrm{pH}$ analysis}

Values of substrate $\mathrm{pH}$ obtained during the colonization of P. ostreatus and L. edode tended to decrease. L. edodes showed the greatest reduction from an average $\mathrm{pH}$ of 5.64 to 3.90 , while $P$. ostreatus resulted in a $\mathrm{pH}$ reduction to a value of 4.26 (Table 1). The one-way Anova Test carried out to compare $\mathrm{pH}$ values obtained for each species during the two periods evaluated showed that there were no significant differences ( $p>$ $0.05)$ after 30 days. However, there was a highly significant difference ( $p>0.01)$ after 60 days of inoculation.

Similar $\mathrm{pH}$ values to those obtained in this study have been previously reported for Pleurotus spp. (Owaid et al., 2017), L. edodes (Ribas et al., 2009), Agaricus subrufescens (Stokness et al. 2019) and many species of fungi (Moore-Landecker, 1996; Chang and Miles, 1989; Deacon, 2006). According to these authors, the decrease in $\mathrm{pH}$ levels can be attributed to the production of organic acids such as gluconic, pyruvic, citric, succinic acids 
Table 1. Main physical parameters of the substrates during the growth of Pleurotus ostreatus and Lentinula edodes.

\begin{tabular}{|c|c|c|c|c|c|c|c|}
\hline Physical parameters & $\begin{array}{l}\text { Time } \\
\text { (days) }\end{array}$ & $\mathrm{pH}$ & $\begin{array}{c}\text { Moisture } \\
\%\end{array}$ & $\begin{array}{c}\text { Lignin } \\
(\mathrm{g} / \mathrm{kg})\end{array}$ & $\begin{array}{c}\text { Cellulose } \\
(\mathrm{g} / \mathrm{kg})\end{array}$ & $\begin{array}{l}\text { Hemicellulose } \\
(\mathrm{g} / \mathrm{kg})\end{array}$ & $\begin{array}{l}\text { C:N } \\
\text { Ratio }\end{array}$ \\
\hline Sterile Sugarcane bagasse & 0 & 5.64 & 81.67 & 91.40 & 494.00 & 275.00 & 36.12 \\
\hline Sugarcane bagasse + Pleurotus ostreatus & 30 & 4.50 & 82.08 & 83.20 & 472.00 & 202.00 & 27.53 \\
\hline Sugarcane bagasse + Pleurotus ostreatus & 60 & 4.26 & 82.45 & 48.30 & 284.00 & 208.00 & 66.88 \\
\hline Sugarcane bagasse + Lentinula edodes & 30 & 4.10 & 82.48 & 87.80 & 491.00 & 186.00 & 31.34 \\
\hline Sugarcane bagasse + Lentinula edodes & 60 & 3.90 & 82.56 & 68.40 & 374.00 & 134.00 & 64.45 \\
\hline
\end{tabular}

and sodium oxalate crystals formed by the fungal metabolism of sugars as well as the formation of carbonic acid, which accumulates in the mycelium of the fungi during growth. Changes in $\mathrm{pH}$ affect the degree of dissociation of mineral salts, balance between dissolved carbon dioxide, bicarbonate ions and net charge of membrane proteins, having consequences for nutrient absorption (Deacon, 2006). On the other hand, levels of acidic $\mathrm{pH}$ could be related to the activity of lignin peroxidase and versatile peroxidases enzymes, produced by $P$. ostreatus and L. edodes to degrade the lignocellulose. These enzymes require acidic $\mathrm{pH}$ values ranging from 3.1 to 4.7 for catalytic functioning (Januzs, 2017). Similarly, enzymes responsible for cellulose degradation, such as endoglucanases, show optimal catalyst values between $\mathrm{pH} 4$ and 5 (Baldrian, 2008).

According to the Colombian Technical Standard 5167, which regulates organic products, the $\mathrm{pH}$ of an organic fertilizer should be between 4 and 9. This means that the $\mathrm{pH}$ of the substrate degraded by $P$. ostreatus specie complies with this regulation, while $L$. edodes does not meet this requirement at a 60-day period. However, when preparing a mixture for a field evaluation, this characteristic can be easily corrected by adding a carbonated material such as Calcium oxide. According to Marschner (2011), soils in arid or semi-arid zones are calcareous, have an alkaline $\mathrm{pH}$ and little organic matter, while plants in those places have micro and macronutrient deficiencies, especially phosphorus. Banik and Dey (1982) reported that the addition of a compost with an acid $\mathrm{pH}$ and depleted by fungi to calcareous soils can increase acidity and biological activity, leading to increases in $\mathrm{CO}_{2}$ production, and thus to the generation of acidic conditions.

\section{Analysis of moisture content}

As P. ostreatus and L. edodes grew during the evaluation period (60 days), moisture did not vary significantly $(p>0.05)$. Moisture content of a substrate strongly influences the acquisition of the necessary nutrients for fungal growth and enzymatic activity. The increase in moisture observed during the growth of both fungal species may be related to the fact that, in the degradation or decomposition process of the substrate, $\mathrm{CO}_{2}$ and water are formed as by-products of the metabolism of the species and degradation of molecules with simple and complex structures (Moore-Landecker, 1996; Hurst et al., 2007).

Moisture levels between 70 and $85 \%$ are recommended to facilitate fungal growth and nutrient availability (Romero et al., 2003). For $P$. ostreatus and L. edodes, levels of $65-75 \%$ (Stamets, 2000) and 77\% (Owaid et al., 2017) have been reported, respectively. In the present study, although moisture content was slightly higher $(82 \%)$, there was no limitation or inhibition of growth (Table 1).

\section{Analysis of C:N ratio}

$P$. ostreatus and L. edodes grew on a substrate with a C:N ratio of 42:1 (Table1), which is within the range reported for species of the same genders. C:N ratio values of 30:1 and 117:1 have been reported for Pleurotus flabellatus (Srivastava and Bano, 1970), 18:1 and 36:1 for P. tuber-regium (Wu et al., 2004), and 85:1 for P. ostreatus (Rajarathnam and Bano, 1989). For Lentinus edodes, the literature has described C:N ratio values of 25:1 (Oei, 1996), 86: 1 (Ribas et al., 2009), and from 110:1 to 140: 1 (Villegas et al., 2007). Nevertheless, Chang and Miles (1989), reported that a C:N ratio of 20:1 is adequate for most fungi, while Hsu and Lo (1999) indicated that a low C:N ratio results in high degradation of organic matter and compost stability. The C: $\mathrm{N}$ ratio is an indicator of the nutritional level of a substrate and largely determines microbial development; therefore, a lack of balance can even impede substrate growth and colonization (Stamets, 2000). However, this parameter can vary according to the strains used, the different stages of development and type of substrate (Gaitán-Hernández et al., 2011).

\section{Cellulose, hemicellulose and lignin analysis}

Lignin, cellulose and hemicellulose contents 
had significant decreases at 60 days for both P. ostreatus and L. edodes (Table 1). P. ostreatus recorded the greatest decrease in lignin $(47.2 \%)$ and cellulose $(42.5 \%)$, while L. edodes showed the greatest hemicellulose degradation (51.3\%). It is noteworthy that the greatest reduction of lignin and cellulose achieved by P. ostreatus was observed at a $\mathrm{pH}$ of 4.3. Cellulose, hemicellulose and lignin are the main sources of carbon and nitrogen (Jamangapé-Ovando, 2018). During mycelium growth and development, biochemical changes result in the production of extracellular enzymes, responsible for degrading the insoluble components and a large amount of lignocellulosic material into soluble and low molecular weight compounds, which are subsequently taken up by intracellular enzymes of the fungus for their nutrition (Kurt and Buyukalaca, 2010; Kudryavtseva et al., 2008). These results support the idea that white rot fungal species vary in terms of the relative rates at which they degrade lignin and lignocellulose carbohydrates (Hatakka, 2001), enzymatic mechanisms, redox systems and radical generation (Baldrian and Valášková, 2007). Additionally, experiments carried out with the white rot fungus Echinodontium taxodii showed that the cellulosic delignification ability varies with the type of wood, being greater in hardwoods than in softwoods (Yu et al., 2009).

In terms of lignin and cellulose degradation, a study on $P$. ostreatus conducted by Benavides (2013) reported values of $59.02 \%$ and $84.23 \%$, respectively, and concluded that such decreases resulted from the increase in mycelium during cultivation, and the extracellular enzymatic activity that generated the mineralization and degradation of the lignocellulosic complex. In our study, levels of lignin degradation were higher than those of cellulose for both $P$. ostreatus and $L$. edodes, and varied slightly between the species with values of $47.2 \%$ and $42.5 \%$, respectively. Pandey and Singh (2014) reported lignin, hemicellulose and cellulose levels of $50.21 \%, 27.73 \%$ and $41.20 \%$, respectively. This is in agreement with the results obtained in the present study, confirming that there is also a decrease in hemicellulose due to mycelium growth and expansion. Montoya et al. (2014) determined that L. edodes is effective in the degradation of lignocellulosic materials, particularly lignin with $51.8 \%$ of degradation.

\section{$\mathrm{N}, \mathrm{P}$ and $\mathrm{K}$ analysis}

Macro and micronutrients depleted by $P$. ostreatus and L. edodes after 60 days of growth are presented in Figs. 1, 2, 3 and 4. It is evident that the resulting substrate presents an increase in

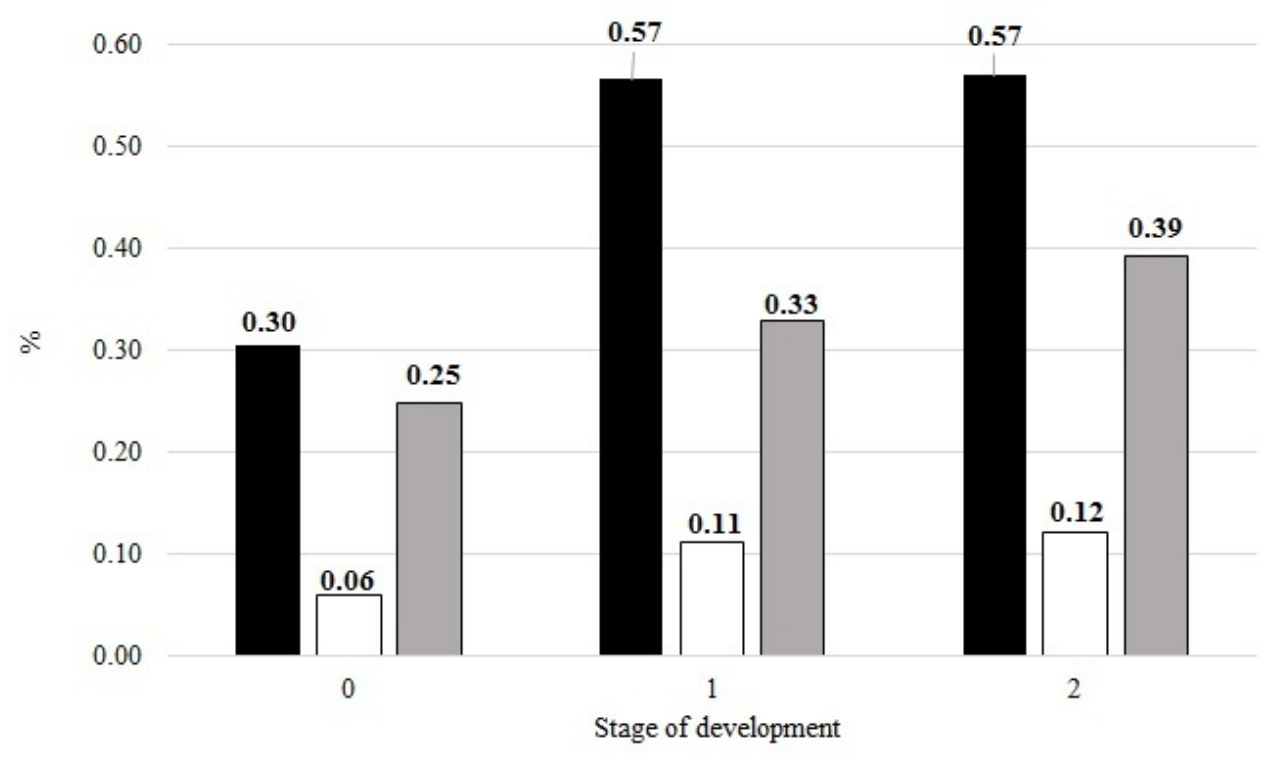

- Nitrogen Pleutotus ostreatus

$\square$ Phosphorus Pleutorus ostreatus

口Potassium Pleurotus ostreatus

Fig. 1. Average NPK variation for Pleurotus ostreatus. Stage of development: 0. Sterile sugarcane bagasse, 1 . Sugarcane bagasse substrate after 30 days of inoculation with $P$. ostreatus, 2. Sugarcane bagasse substrate after 60 days of inoculation with $P$. ostreatus. 


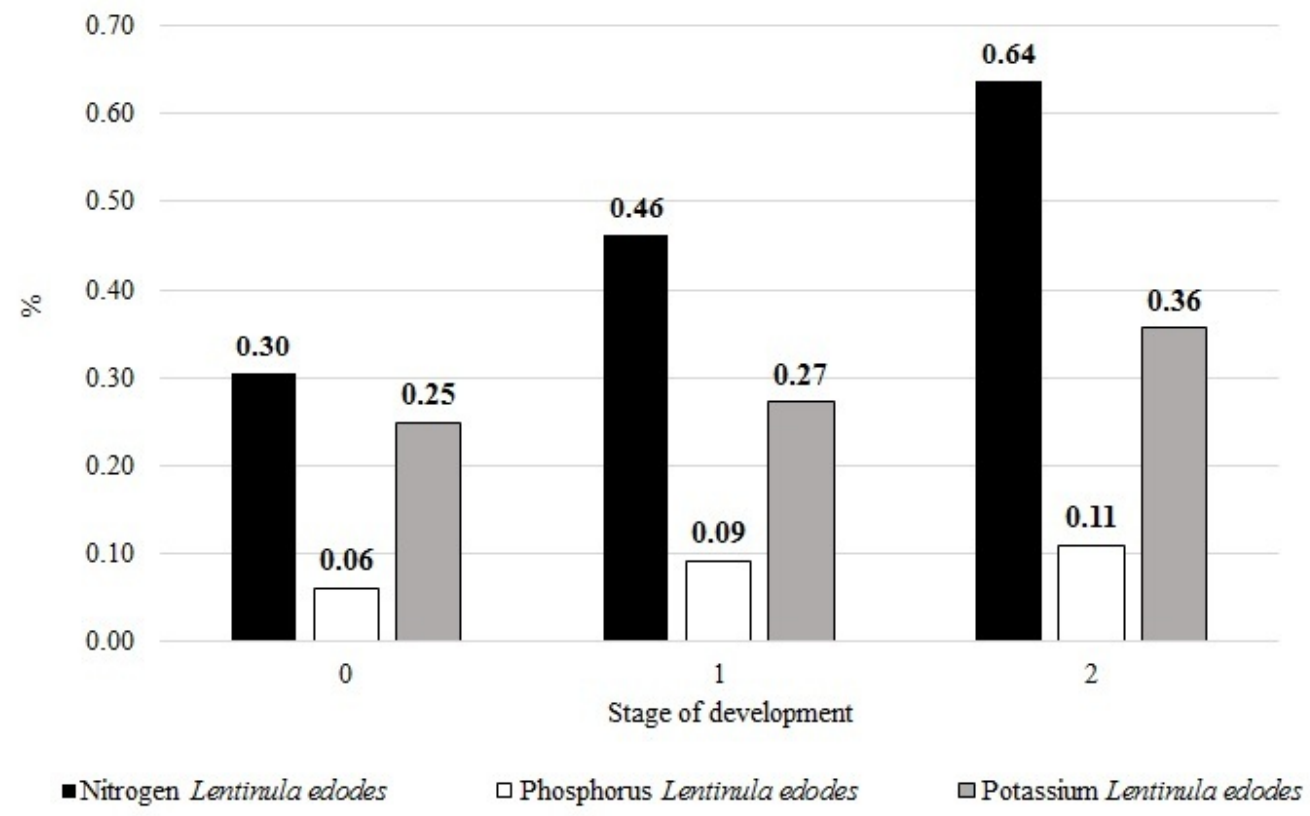

Fig. 2. Average NPK variation for Lentinus edodes. Stage of development: 0 . Sterile sugarcane bagasse, 1. Sugarcane bagasse substrate after one 30 days of inoculation with L. edodes, 2 . Sugarcane bagasse substrate after 60 days of inoculation with L. edodes.

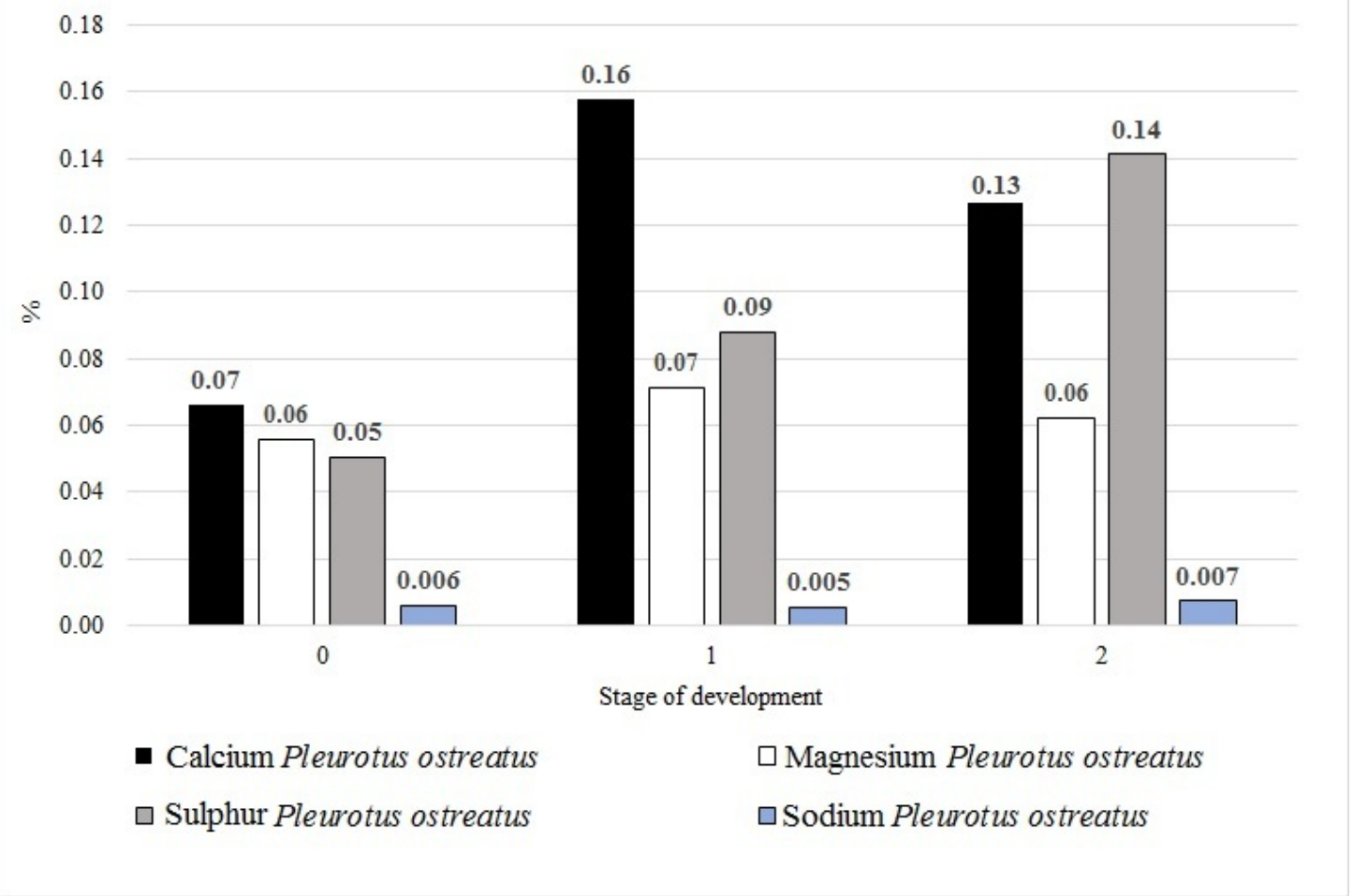

Fig. 3. Average of $\mathrm{Ca}, \mathrm{Mg}, \mathrm{S}$ and $\mathrm{Na}$ variation for Pleurotus ostreatus. Stage of development: 0 . Sterile sugarcane bagasse, 1 . Sugarcane bagasse substrate after 30 days of inoculation with $P$. ostreatus, 2. Sugarcane bagasse substrate after 60 days of inoculation with P. ostreatus. 


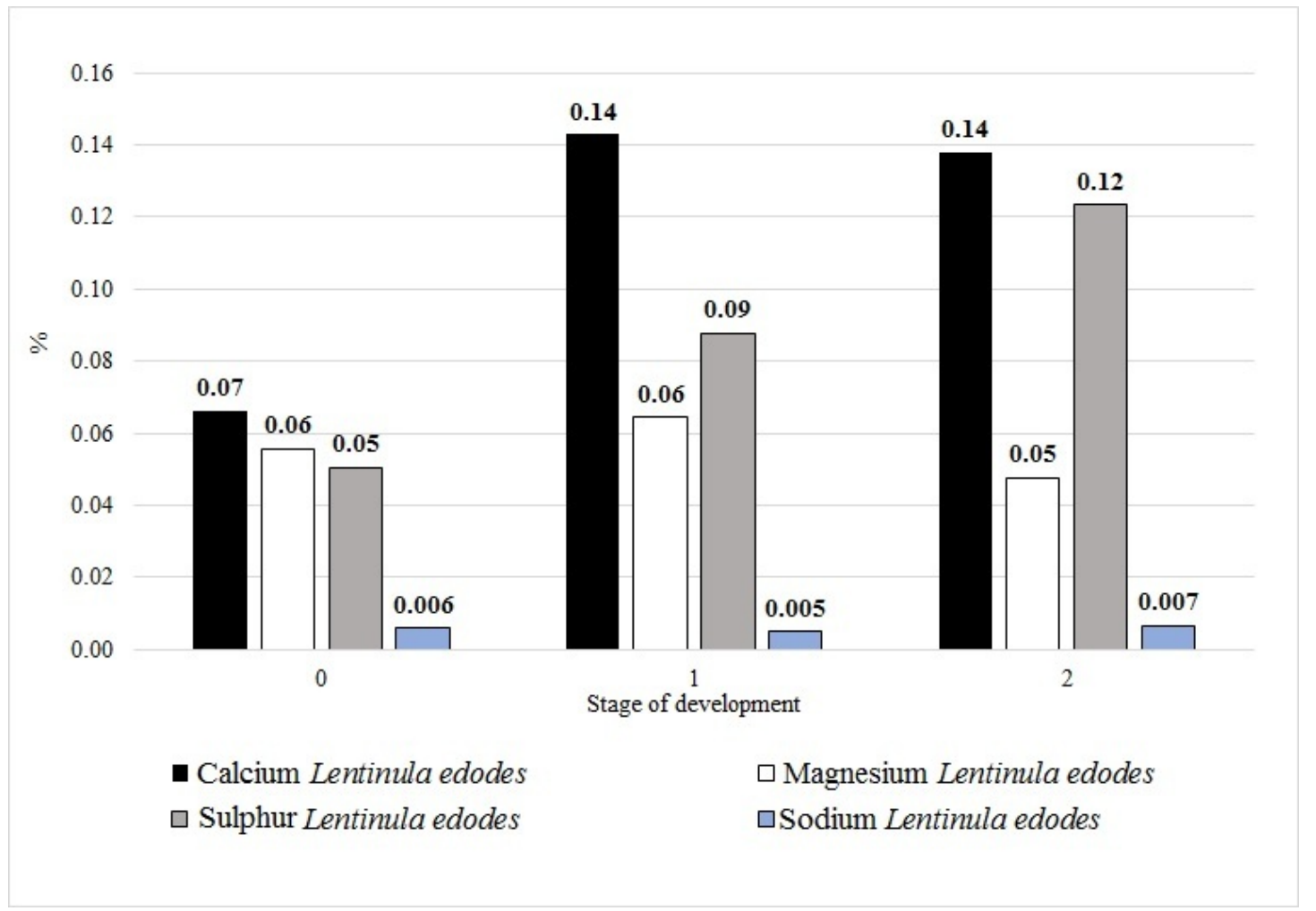

Fig. 4. Average of $\mathrm{Ca}, \mathrm{Mg}, \mathrm{S}$ and $\mathrm{Na}$ variation for Lentinula edodes. Stage of development: 0 . Sterile sugarcane bagasse, 1 . Sugarcane bagasse substrate after 30 days of inoculation with L. edodes, 2. Sugarcane bagasse substrate after 60 days of inoculation with L. edodes.

primary macronutrients $(\mathrm{N}, \mathrm{P}, \mathrm{K})$ and secondary macronutrients $(\mathrm{Ca}, \mathrm{Mg}, \mathrm{S}$ and $\mathrm{Na})$ after the growth of the two species studied.

$\mathrm{N}$ content in the depleted substrate was similar for both species during the evaluation period. Average values of $5.69 \mathrm{~g} / \mathrm{kg}(0.569 \%)$ and $6.38 \mathrm{~g}$ / $\mathrm{kg}(0.638 \%)$ were obtained for P. ostreatus and $L$. edodes, respectively. Phosphorus content behaved in a similar way, reaching values of $1.21 \mathrm{~g} / \mathrm{kg}$ $(0.121 \%)$ for P. ostreatus and $1.09 \mathrm{~g} / \mathrm{kg}(0.109 \%)$ for $L$. edodes. The final potassium content in the substrate was $3.92 \mathrm{~g} / \mathrm{kg}(0.392 \%)$ and 3.56 $\mathrm{g} / \mathrm{kg}(0.356 \%)$ for P. ostreatus and L. Edodes, respectively. The one-way Anova performed to compare the values obtained for each species showed no significant differences ( $p>0.05$ ). These results agree with those obtained by Owaid et al. (2017), who reported nitrogen levels of $6.65 \mathrm{~g} / \mathrm{kg}$ in a substrate depleted by $P$. salmoneostramineus, made of $50 \%$ wheat straw $+30 \%$ sawdust, and $20 \%$ palm fiber. Additionally, $\mathrm{N}$ content reached 9.98 $\mathrm{g} / \mathrm{kg}$ in another substrate depleted by P. ostreatus based on $50 \%$ wheat straw, $30 \%$ sawdust and $20 \%$ palm fiber, due to the fact that they started from twice the initial content of the substrate used in the present study $(3.05 \mathrm{~g} / \mathrm{kg})$. In the case of $L$. edodes, Ribas et al. (2009) found an equal value for
$\mathrm{N}$ in a substrate made up of eucalyptus sawdust + $10 \%$ rice bran + gypsum and $\mathrm{CaCO}_{3}$. Experiments carried out by Medina et al. (2009) showed that the $\mathrm{N}$ content in different mixtures of compost spent by $P$. ostreatus + commercial Sphagnum varied from $11-13 \mathrm{~g} / \mathrm{kg}$.

Rao et al. (2007) highlighted that as a spent substrate presents high variability and chemical imbalance, it is necessary to replace the missing chemicals in order to be used as a fertilizer. In the present study, the nitrogen level in the compost degraded by $P$. ostreatus and L. edodes was below the optimal range required for organic fertilizers, and therefore a mixture with other plant residues with higher $\mathrm{N}$ content can be used to start with a substrate richer in $\mathrm{N}$ from its initial formulation when the substrate was not supplemented during the initial phase. On the other hand, it would be interesting to make mixtures of compost depleted by these species and compost depleted by Agaricus subrufescens, which has an $\mathrm{N}$ content of $1.8 \%$, in order to achieve acceptable levels of $\mathrm{N}$ for an organic fertilizer, which range from 1 to $2 \%$ (10-20g / kg) (Alexander, 1994).

Regarding levels of phosphorus (P) and potassium (K), Alexander (1994), defined that the optimal range for organic compost varies from 
$0.6 \%$ to $0.9 \%$ for $\mathrm{P}$ and from $0.2 \%$ to $0.5 \%$ for $\mathrm{K}$. In In the present study, the SMS of P. ostreatus and $L$. edodes showed low levels of phosphorus, with values of $0.12 \%$ and $0.11 \%$, respectively. However, they may represent a good source of $\mathrm{K}$, with values of $0.39 \%$ and $0.36 \%$, respectively. Ribas et al. (2009) also reported levels of $0.58 \%$ and $0.17 \%$ for $\mathrm{P}$ and $\mathrm{K}$, respectively, in a substrate of L. edodes based on eucalyptus sawdust and $10 \%$ rice bran. The disparity in the results suggests that more studies are needed to balance the appropriate levels of these elements in a substrate. It is important to note that $\mathrm{P}$ bioavailability depends on the contents of organic matter, $\mathrm{Ca}, \mathrm{Fe}$ and $\mathrm{Al}$ as well as $\mathrm{pH}$ of the medium since $\mathrm{P}$ is more bioavailable to plants at $\mathrm{pH}$ between 6 and 7 (Chang et al., 2014).

\section{$\mathrm{Ca}, \mathrm{Mg}$, $\mathrm{S}$ and $\mathrm{Na}$ Analysis}

Values of secondary macro elements such as calcium, magnesium, sulfur and sodium showed different trends from the formulation stage until completion of the 60-day evaluation period for both P. ostreatus and L. edodes. Fig. 2 shows the percentage of each element during the three evaluation periods ( 0,30 and 60 days).

Calcium increased in a very similar way in both species, reaching an average content of $0.7 \%$, while there was no considerable increase for sodium and magnesium. Sulfur behaved very similarly in the two species, recording an increase of $0.09 \%$ and $0.07 \%$ for P. ostreatus and L. edodes, respectively; the content of this element in the agro-industrial substrate was $0.051 \%(0.51) \mathrm{g} / \mathrm{kg}$. $P$. ostreatus recorded an average value of $0.141 \%$ $(1.41 \mathrm{~g} / \mathrm{kg})$, while the final average value reached by L. edodes was $0.123 \%(1.23 \mathrm{~g} / \mathrm{kg})$.

Maszkiewicz (2010) extensively documented the high $\mathrm{Ca}, \mathrm{Mg}, \mathrm{Na}$ and $\mathrm{S}$ contents in the residual compost of Agaricus bisporus. Postemsky and López-Castro (2016) reported that a compost degraded by $P$. ostreatus based on sunflower shell and supplemented with $2 \%$ and $0.5 \%$ of calcium sulfate $\left(\mathrm{CaSO}_{4}\right)$ and calcium carbonate $\left(\mathrm{CaCO}_{3}\right)$, respectively, contained $1305 \mathrm{mg} / \mathrm{kg}$ of $\mathrm{Ca}, 30 \mathrm{mg}$ / $\mathrm{kg}$ of Na, $173 \mathrm{mg} / \mathrm{kg}$ of $\mathrm{Mg}$ and $170 \mathrm{mg} / \mathrm{kg}$ of $\mathrm{S}$.

\section{CONCLUSIONS}

The increase in nutrients observed in the material resulting after the growth of Pleurotus ostreatus and Lentinula edodes in sugarcane bagasse can be used to develop a suitable organic amendment by adding plant residues rich in nitrogen, phosphorus, potassium, calcium, total minerals, fat and fiber beginning from the initial stage of compost formulation to obtain an appropriate C:N ratio. An optimum C:N relation allows for better mycelial growth, and consequently an improved synthesis of proteins and other minerals in the substrate. The addition of this substrate can contribute to the recovery of soils that have undergone processes of degradation, salinization, extensive use of chemical fertilizers, or that are deficient in nutrients. It is well known that this material is rich in organic matter so that its use could improve parameters related to soil structure such as porosity, aeration, and water movement. Similarly, given the decrease in $\mathrm{pH}$, which occurs naturally as fungal mycelium grows due to the production of various metabolites, the resulting substrate could be used to treat and modify calcareous soils once appropriate doses and mixtures are determined. Finally, the decomposition and delignification carried out by these two species of fungi are crucial steps in the process of organic matter humidification.

\section{ACKNOWLEDGMENTS}

The author would like to thank the Universidad del Valle, Cali, Colombia for the financial support from Internal Call 2017 for research projects.

\section{LITERATURE CITE}

Abad, M., P. Noguera, and S. Bures. 2001. National inventory of organic wastes for use as growing media for ornamental potted plant production: case study in Spain. Bioresource Technology 77:197-200. https:// doi.org/10.1016/S0960-8524(00)00152-8

Ahmad, Z.M., I. Khan, B. Shah, A. Naeem, N. Khan, W. Ullah, et al. 2016. Study on the management of Ralstonia solanacearum (Smith) with spent mushroom compost. Journal of Entomology and Zoology Studies 4(3): 114-121. https://www.researchgate.net/ publication/302411979

Alexander, R.A. 1994. Standards and guidelines for compost use. Biocycle 35:37-41.

Appels, F.V.W., J. Dijksterhuis, C.E. Lukasiewicz, K.M.B Jansen, HAB. Wösten, and P. Krijgsheld. 2018. Hydrophobin gene deletion and environmental growth conditions impact mechanical properties of mycelium by affecting the density of the material. Scientific Reports 8:470. https://doi. org/10.1038/s41598-018-23171-2

Ayala, M., S.S. Gonzalez-Munoz, J. M. PinosRodríguez, C. Vázquez, M. Meneses, O. Loera, and G.D. Mendoza. 2011. Fibrolytic potential of spent compost of Agaricus bisporus to degrade forages for ruminants. African Journal of Microbiology Research 5:643-650. https://doi.org/10.5897/AJMR10.528 
Baldrian, P., and V. Valášková. 2008. Degradation of cellulose by Basidiomycetous fungi. FEMS Microbiology Reviews 32:501-521. https:// doi.org/10.1111/j.1574-6976.2008.00106.x

Balesdent, J., C. Chenu, and M. Balabane. 2000. Relationship of soil organic matter dynamics to physical protection and tillage. Soil \& Tillage Research 53:215-230. https://doi. org/10.1016/S0167-1987(99)00107-5

Banik, S., and B.K. Dey. 1982. Available phosphate content of an alluvial soil as influenced by inoculation of some isolated phosphatesolubilizing microorganisms. Plant and Soil 69:353-364. https://doi.org/10.1007/ BF02372456

Becerra-Quiroz, A. P., A. L. Buitrago-Coca, y P. Pinto-Baquero. 2016. Sostenibilidad del aprovechamiento del bagazo de caña de azúcar en el Valle del Cauca, Colombia. Ingeniería solidaria, 12: 133-149. https://doi. org/10.16925/in.v12i20.1548

Benavides O., L. 2013. Aprovechamiento de residuos lignocelulósicos para el cultivo de orellnas (Pleurotus ostreatus). Tesis Magister en Ciencias Agrarias, Universidad de Nariño, Colombia. http://sired.udenar.edu. co/2527/1/89544.pdf

Cárdenas, M., J. Echavarrí, G. Hernández, A. Maiguashca, A. Meisel, J. Ocampo, and J. Zárate. 2018. Recuadro 2 del informe al congreso marzo de 2018: Coyuntura del sector agropecuario colombiano. Banco de la Republica de Colombia. https://www.banrep. gov.co/sites/default/files/publicaciones/ archivos/informe-congreso-marzo-2018recuadro-2. Consulted July 7th 2020.

Chang, S.Ch., M.J. Lin, Y.P. Chao, CH.J. Chiang, Yu-Sh. Jea, and T.T. Lee. 2016. Effects of spent mushroom compost meal on growth performance and meat characteristics of grower geese. Revista Brasileira de Zootecnia 45:281-287. https://www.scielo.br/pdf/rbz/ v45n6/1516-3598-rbz-45-06-00281

Chang, H.Y., O.H. Ahmed, and N.M.A. Majid. 2014. Improving phosphorus availability in an acid soil using organic amendments produced from agroindustrial wastes. The Scientific World Journal, 2014. https://doi. org/http://dx.doi.org/10.1155/2014/506356.

Chang, S.T., and S.P. Wasser. 2012. The role of culinary-medicinal mushrooms on human welfare with a pyramid model for human health. International Journal of Medicinal Mushrooms, vol. 14:95-134. https://doi. org/10.1615/IntJMedMushr.v14.i2.10

Chang, S.T., and P.G. Miles. 1989. Edible Mushrooms and their Cultivation. CRC Press, Florida, USA.
Deacon, J. 2006. Fungal Biology. 4th ed. Blackwell Publishing Ltd. Oxford, UK.

Foluke, A., A. Olutayo, and A. Olufemi. 2014. Assessing spent mushroom substrate as a replacement to wheat bran in the diet of broilers. American International Journal of Contemporary Research 4: 178-183. https://www.researchgate.net/ publication/269334643

Gaitán-Hernández, R., M. Esqueda, A.H. Gutiérrez-Saldaña, and M. Beltrán-García. 2011. Quantitative changes in the biochemical composition of lignocellulosic residues during the vegetative growth of Lentinula edodes. Brazilian Journal of Microbiology 42:30-40. https://doi.org/10.1590/S151783822011000100004

Gerdelidani, A.F., and A.H.M. Hosseini. 2018. Effects of sugar cane bagasse biochar and spent mushroom compost on phosphorus fractionation in calcareous soils. Soil Research. 56:136-144. https://doi.org/10.1071/ SR17091

Gümüş, I., and C. Şeker. 2017. Effects of spent mushroom compost application on the physicochemical properties of a degraded soil. Solid Earth, 8:1153-1160. https://doi. org/10.5194/se-8-1153-2017

Hatakka, A. 2001. Biodegradation of lignin. p. 129-167. In: M. Hofrichter, A. Steinbüchel (Ed.), Lignin, Humic Substances and Coal: Wiley-VCH, Helsinki, FI.

Heleno, S.A., L. Barros, M.J. Sousa, A. Martins, and I. Ferreira. 2010. Tocopherols composition of Portuguese wild mushrooms with antioxidant capacity. Food Chemistry 119:443-1450. https://doi.org/10.1016/j. foodchem.2009.09.025

Hiyama, R., S. Gisusi, and A. Harada. 2011. Evaluation of waste mushroom medium from cultivation of shiitake mushroom (Lentinula edodes) as feedstock of enzymatic saccharifi cation. Journal of Wood Science 57:429-435. https://doi.org/10.1007/s10086011-1185-y

Hsu, J-H., and S-L. Lo. 1999. Chemical and spectroscopic analysis of organic matter transformations during composting of pig manure. Environmental Pollution 104:189-196. https://scholars.lib.ntu.edu.tw/ bitstream/123456789/77320/1/22.pdf

Hurst, C., R.Crawford, J. Garland, D. Lipson, A. Mills. and L. Stetzenbach. 2007. Manual of environmental microbiology. ASM Press, Washington, USA.

Jamangapé, O. R. G. 2018. Cultivo y elaboración de productos a base de setas. Universidad de Ciencias y Artes de Chiapas, Mexico. 
Jankowski, K., E. Malinowska, J. Sosnowski, B. Wiśniewska-Kadżajan, and A. Kaczorek. 2018. Effects of spent mushroom substrate and slurry on nutritional value of grass and Medicago x varia T. Martyn mixtures. International Journal Agricultural and Biological Engineering 11:61-66. https://doi. org/10.25165/j.ijabe.20181103.3726

Janusz, G., A. Pawlik, J. Sulej, U. Świderska-Burek, A. Jarosz-Wilkołazka, and A. Paszczyński. 2017. Lignin degradation: microorganisms, enzymes involved genomes analysis and evolution. FEMS Microbiology Reviews 41: 941-962. https://doi.org/10.1093/femsre/ fux049

Jones, M.P., T. Huynh, C. Dekiwadia, f. Daver, and J. Sabu. 2017. Mycelium composites: a review of engineering characteristics and growth kinetics. Journal of Bionanoscience 11:241257. https://doi.org/10.1166/jbns.2017.1440

Kabel, M.A., E. Jurak, M.R. Mäkelä, R. P. de Vries. 2017. Occurrence and function of enzymes for lignocellulose degradation in commercial Agaricus bisporus cultivation. Applied Microbiology and Biotechnology 101:43634369. https://doi.org/10.1007/s00253-0178294-5

Kamthan, R., and I. Tiwari. 2017. Agricultural Wastes- potential Substrates for Mushroom cultivation. European Journal of Experimental Biology, 7:1-4. https://doi. org/10.21767/2248-9215.100031

Kim, Y.I., W.M. Cho, S.K. Hong, Y.K. Oh, and W.S. Kwak. 2011. Yield, nutrient characteristics, ruminal solubility, and degradability of spent mushroom (Agaricus bisporus) substrates for ruminants. Asian-Australia Journal of Animal Science 24:1560-1568.

Kudryavtseva, O., Y. Dunaevsky, O. Kamzolkina, and M. Belozersky. 2008. Fungal Proteolytic Enzymes: Features of the Extracellular Proteases of Xylotrophic Basidiomycetes. Microbiology 77:643-653. https://doi. org/10.1134/S0026261708060015

Kurt, S., and S. Buyukalaca. 2010. Yield performances and changes in enzyme activities of Pleurotus spp. (P. ostreatus and $P$. sajor-caju) cultivated on different agricultural wastes. Bioresource Technology, 101: 3164. https://doi.org/10.1016/j.biortech.2009.12.011

Law, W., W. Lau, K. Lo, L. Wai, and S. Chiu. 2003. Removal of biocide pentachlorophenol in water system by the spent mushroom compost of Pleurotus pulmonarius. Chemosphere 52: 1531-1537. https://doi. org/10.1016/s0045-6535(03)00492-2
Lim, S.H., Y-H. Lee, and H.W Kang. 2013. Efficient Recovery of Lignocellulolytic Enzymes of Spent Mushroom Compost from Oyster Mushrooms, Pleurotus spp., and Potential Use in Dye Decolorization. Mycobiology 41: 214-220. https://doi.org/10.5941/ MYCO.2013.41.4.214

Liu, Y., CH. Zhao, D. Lin, H. Lin, and Zh. Lin. 2015. Effect of water extract from spent mushroom substrate after Ganoderma balabacense cultivation by using JUNCAO technique on production performance and hematology parameters of dairy cows. Animal Science Journal 86: 855-862. https://doi.org/10.1111/ asj.12371.

Malusà, E., F. Pinzari, and I. Canfora. 2016. Efficacy of biofertilizers: challenges to improve crop production. p. 17-40. In D.P. Singh et al. (ed.). Microbial inoculants in sustainable agricultural productivity. Springer, New Delhi, IN.

Marín-Benito, J.M., M.J. Sánchez-Martín, and M.S. Rodríguez-Cruz. 2016. Impact of Spent Mushroom Substrates on the Fate of Pesticides in Soil, and Their Use for Preventing and/or Controlling Soil and Water Contamination: A Review. Toxics 4:224. https://doi.org/10.3390/toxics4030017

Marschner, H. 2011. Mineral nutrition of higher plants. 3rd ed. Academic press, London UK.

Maszkiewicz, J. 2010. Used mushroom substrate as fertilizer and fuel. In Mushrooms. Mushroom Producer Bulletin. Wyd. Hortpress 1:59-60. (in Polish)

Medina, E., C. Paredes, M.A. Bustamante, R. Moral, and J. Moreno-Caselles. 2012. Relationships between soil physico-chemical, chemical and biological properties in a soil amended with spent mushroom substrate. Geoderma 173-174:152-161. https://doi. org/10.1016/j.geoderma.2011.12.011

Medina, E., C. Paredes, M.D. Pérez-Murcia, M.A. Bustamante, and R. Moral. 2009. Spent mushroom substrates as component of growing media for germination and growth of horticultural plants. Bioresource Technology 100:4227-4232. https://doi. org/10.1016/j.biortech.2009.03.055

Montoya, B., S. Sánchez and L. Levin. 2014. Evaluation of endoglucanase, exoglucanase, laccase, and lignin peroxidase activities on ten white-rot fungi. Biotecnología en el Sector Agropecuario y Agroindustrial 12:115-124. Retrieved from http://www.scielo.org.co/ pdf/bsaa/v12n2/v12n2a13.pdf

Moore-Landecker. E. 1.996. Fundamentals of the fungi. 4th ed. Prentice-Hall, Inc. New Jersey, USA. 
Nakatsuka, H., M. Oda, Y. Hayashi, and K. Tamura. 2016. Effects of fresh spent mushroom substrate of Pleurotus ostreatus on soil micromorphology in Brazil. Geoderma 269: 54-60. http://dx.doi.org/10.1016/j. geoderma.2016.01.023

Oei, P. 1996. Mushroom cultivation. Tool Publications, Leiden, The Netherlands.

Outzouni, P.K., D. Petridis, W.D. Koller, and K.A. Riganakos. 2009. Nutritional Value and metal content of wild edible mushrooms collected from west Macedonia and Epirus Greece. Food Chemistry 115: 1575-1580. https://doi. org/10.1016/j.foodchem.2009.02.014

Owaid, M.M., I.A. Abed, and S.S.S. Al-Saeedi. 2017. Applicable properties of the biofertilizer spent mushroom substrate in organic systems as a byproduct from the cultivation of Pleurotus spp. Information processing in Agriculture 4:78-82. https://doi. org/10.1016/j.inpa.2017.01.001

Pandey, V.K., and M.P.Singh.2014.Biodegradation of wheat straw by Pleurotus ostreatus. Cellular and Molecular Biology 60:29-35. https://doi. org $/ 10.14715 / \mathrm{cmb} / 2014.60 .5 .6$

Pardo-Giménez, A., L. Catalán, J. Carrasco, M. Álvarez-Ortí, D. Zied, and J. Pardo. 2016. Effect of supplementing crop substrate with defatted pistachio meal on Agaricus bisporus and Pleurotus ostreatus production. J. Sci. Food Agric. 96(11): 3838-3845. https://doi. org/10.1002/jsfa.7579

Pardo-Giménez, A., J. Carrasco, J.M. Roncero, M. Álvarez-Ortí, D.C. Zied and J.E. PardoGonzález. 2018. Recycling of the biomass waste defatted almond meal as a novel nutritional supplementation for cultivated edible mushrooms. Acta Scientiarum. Agronomy 40: e39341. DOI: 10.4025/ actasciagron.v40i1.39341

Phan, C.W., and V. Sabaratnam. 2012. Potential uses of spent mushroom substrate and its associated Lignocellulosic enzymes. Applied Microbiology \& Biotechnology 96:863-873. https://doi.org/10.1007/s00253-012-4446-9

Postemsky, P. D., and R. I. López-Castro. 2016. Aplicaciones de sustrato residual del cultivo de hongos en la producción hortícola. Horticultura Argentina 35: 44-63. https://www.researchgate.net/ publication/310648661

Rajarathnam, S., and Z. Bano. 1989. Pleurotus mushrooms: part III. Biotransformation of natural lignocellulosic wastes: commercial applications and implications. Critical Reviews in Food Science and Nutrition 28:31-113.
Rao, J.R., M. Watabe, T.A. Stewart, B.C. Millar, and J.E. Moore. 2007. Pelleted organomineral fertilizers from composted pig slurry solids, animal wastes and spent mushroom compost for amenity grasslands. Waste Management 27:1117-1128.

Raymond, P., A.M. Mshandete, and A.K. Kivaisi. 2015. Enzyme Profiles of Pleurotus HK-37 During Mycelia Vegetative Growth and Fruiting on Solid Sisal Waste Fractions Supplemented with Cow Manure. Advances in Biochemistry 3:57-65.

Ribas, L.C.C., M.M. Mendonça, C.M. Camelini, and C.H.L. Soares. 2009. Use of spent mushroom substrates from Agaricus subrufescens (syn. A. blazei, A. brasiliensis) and Lentinula edodes productions in the enrichment of a soilbased potting media for lettuce (Lactuca sativa) cultivation: growth promotion and soil bioremediation. Bioresource Technology 100:4750-4757. https://doi.org/10.1016/j. biortech.2008.10.059

Ritz, K., and I.M. Young. 2004. Interactions between soil structure and fungi. Mycologist 18: 52-59. https://doi.org/10.1017/S0269915X(04)00201-0

Rodríguez-da luz, J.M., M. Nunes-Días, S. Albino-Paes, D. Pereira-Torres, M. Soares da Silva, and M.C. Megumi-Kasuya. 2012. Lignocellulolytic enzyme production of Pleurotus ostreatus growth in agroindustrial wastes. Brazilian Journal of Microbiology 43: 1508-1515. http://dx.doi.org/10.1590/S151783822012000400035

Romero, A., A. Rodríguez, and M. Pérez. 2003. Pleurotus ostreatus. Importancia y tecnología de cultivo. Universidad de Cienfuegos "Carlos Rafael Rodríguez", Cuatro Caminos, Cdad. Cienfuegos, Cuba.

Royse, D.J., J. Baars, and Q. Tan. 2017. Current overview of mushroom production in the world. P. 5-13. In D.C. Zied, Pardo-Giménez A. (ed.). Edible and medicinal mushrooms: technology and applications. John Wiley \& Sons Ltd. Hoboken, New Jersey, USA. https:// doi.org/10.1002/97811 19149 446.ch2

Sari, M., R. Hambitzer, J. Lelley, K. Toepler, N. Teusch, and A. Nickisch-Hartfiel. 2016. Characterization of cross flow ultrafiltration fractions from Grifola frondosa revealed distinct cytotoxicity in tumor cells. International Journal for Medicinal Mushrooms 18:671-680. Singh, M.P., and V.K. Singh. 2012. Biodegradation of vegetable and agrowastes by Pleurotus sapidus: A noble strategy to produce mushroom with enhanced yield and nutrition. Cellular and Molecular Biology 58:1-7. 
Srivastava, H. C., and Z. Bano. 1970. Nutrition requirements of Pleurotus flabellatus. Applied and Environmental Microbiology 19:166-169.

Stamets, P. 2000. Growing gourmet and medicinal mushroom. Third ed. Ten Speed Press, Toronto, CA.

Stanley, H.O., S.N. Maeba, D.K. Gbenekanu, and C.J. Ugboma. 2018. Crude Oil Degradation Using Spent Mushroom Compost (SMC) of Pleurotus florida. Asian Journal of Advanced Research and Reports 2:1-7. https://doi. org/10.9734/AJARR/2018/44326

Stoknes, K., E. Wojciechowska, A. Jasinska, and R. Noble. 2019. Amelioration of Composts for Greenhouse Vegetable Plants Using Pasteurized Agaricus Mushroom Substrate. Sustainability 11: $6779 . \quad$ https://doi. org/10.3390/su11236779

Tisdall, J.M., and J.M. Oades. 1982. Organicmatter and water-stable aggregates in soils. Journal of Soil Science 33:141-163. https://doi. org/10.1111/j.1365-2389.1982.tb01755.x

Unal, M. 2015. The utilization of spent mushroom compost applied at different rates in tomato (Lycopersicon esculentum Mill.) seedling production. Emirates Journal of Food and Agriculture 27:692-7. https://doi.org/10.9755/ ejfa.2015-05-206

Villegas, V., A.M. Pérez, and C. Arredondo. 2007. Evaluación de la producción del hongo Lentinula edodes Pegler en bloques sintéticos a partir de residuos agroindustriales. Ingeniería y Ciencia 6:23-39. https://www. researchgate.net/publication/28220574

Vos, A.M., E. Jurak, J.F. Pelkmans, K. Herman, G. Pels, J.J. Baars, et al. 2017. $\mathrm{H}_{2} \mathrm{O}_{2}$ as a candidate bottleneck for MnP activity during cultivation of Agaricus bisporus in compost. AMB Express 7:124. https://doi.org/10.1186/ s13568-017-0424-z
Wang, S., F. Xu, Z. Li, S. Zhao, S. Song, Ch. Rong, et al. 2015. The spent mushroom substrates of Hypsizigus marmoreus can be an effective component for growing the oyster mushroom Pleurotus ostreatus. Scientia Horticulturae 186: 217-222. https://doi.org/10.1016/j. scienta.2015.02.028

Wu, J.Z., P.C.K. Cheung, K.H. Wong, and N.I. Huang. 2004. Studies on submerged fermentation of Pleurotus tuber-regium (Fr.) Singer. Part 2: effect of carbon-nitrogen ratio of culture medium on the content and composition of the mycelial dietary fibre. Food Chemistry. 85:101-105. https://doi. org/10.1016/j.foodchem.2003.06.009

Xing, Y., M. Brewer, H. El-Gharabawy, G. Griffith, and P. Jones. 2018. Growing and testing mycelium bricks as building insulation materials. IOP Conf Ser: Earth Environmental Science 121:022032. https:// doi.org/10.1088/1755-1315/121/2/022032

Yu, H., G. Guo, X. Zhang, K. Yan, and C. Xu. 2009. The effect of biological pretreatment with the selective white-rot fungus Echinodontium taxodii on enzymatic hydrolysis of softwoods and hardwoods. Bioresource Technology 100:5170-5.

Zhu, H., k. Sheng, E. Yan, J. Qiao, and F. Lv. 2012. Extraction, purification and antibacterial activities of a polysaccharide from spent mushroom substrate. International Journal of Biological Macromolecules 50:840- 843. https://doi.org/10.1016/j.ijbiomac.2011.11.016 